\title{
Garfield, Seth \\ In Search of the Amazon: Brazil, the United States, and the Nature of a Region
}

Regina Horta Duarte*

Durham: Duke University Press, 2014. 343p.

In the first pages of his book In Search of the Amazon, Seth Garfield evokes old reports of explorers - emotional narratives of Herculean trips - to present his own enterprise of years of investigation about the Amazon. The old narratives of travels to which the author alludes, however, represents the tropical environment using well-established identities and counterpoised to the European world, founding myths and establishing prejudice. Differently, we are not facing a refined historic reflections which causes us to question what we know about the Amazon. With him we tread - page by page - the trails built in the past by various historic actors, continually remade and redirected in the game of social and political confrontations. Armed with meticulous documentary research and willing to enter unexplored territory, Garfield dismantles traps of entrenched identity, concepts, and representations pretensions. He demonstrates how the successful search for an Amazonian essence implies the conclusion that it had no essence at all, since it is a place that is historically produced in intricate social relations on the local, regional, national, and global scales. With such a perspicacious guide, it becomes a stimulating intellectual adventure to enter the forest. Garfield is part of the best type of historians, since, as Marc Bloch says (n.d., p.28), "where human flesh can be smelt, know that its prey is there."

The theme of the exploration of rubber in the Brazilian Amazon during the Estado Novo conducts the book. Despite continually referring to the golden period of this commodity in Brazil between 1870 and 1910, and dedicating the epilogue to the representations and practices which delineated the Amazon from the 1970s to the present day, the principal focus is concentrated on the Second World War. The contraband of seeds of Hevea brasiliensis, the rubber

\footnotetext{
* Department of History, Universidade Federal de Minas Gerais.CNPq Researcher. reginahortaduarte@ gmail.com
} 
tree, to Southeast Asia in 1876, and the success of new plantations in the first decades of the twentieth century established an international competition in which Brazil emerged defeated: at the beginning of the 1930s, the Amazon produced less than $1 \%$ of the rubber consumed in the world.

Nevertheless, with the start of the March to the West as a national integration project by Vargas and the Japanese conquest of Southeast Asia in 1941, the Amazon emerged as a strategic location for the supply of this raw material. In Search of the Amazon concentrates on the political, cultural, and environmental analysis of the region, accompanied by the production of multiple meanings for the Amazon, in the intermeshing of social practices and disputes for power.

The Amazon is analyzed as a place instituted in historical temporality by a myriad of subjects who, in turn, face the conditions of the physical environment. Garfield dialogues with the geographer David Harvey, for whom places are material and ecological artifacts constructed and felt in the middle of the intricate networks of social relations, full of symbolic meanings and representations, social products of political and economic powers. Like Bruno Latour, the author argues that 'nature' is inseparable from social representations, and that society also results from non-human elements. Like Roger Chartier, he considers social conflicts in light of the tensions between the inventiveness of individuals and the conditions outlined by the norms and conventions of his own time. These horizons need to be evaluated in the investigation of what men and women thought, did, and expressed.

Garfield poked around archives in Belém, Fortaleza, Manaus, Porto Velho, Rio Branco and Rio de Janeiro, as well as the United States. He faced various conditions of conservation, organization, and access of the collections, in which he found newspapers of the period published in various cities, bulletins and service magazines linked to rubber, radio programs, newsreels, scientific papers from various areas of knowledge, interviews with northeastern migrants, criminal and civil law cases, various reports, the personal correspondence of men and women involved in the saga of the 1940s 'rubber soldiers,' novels about the Amazon, cordel literature, and photographs. The image are the touchstone of the capricious edition of the book. Twenty-eight photographs - as well as figures and maps - privilege urban aspects of Manaus and Belém, scenes of work and daily life, poses political and technical authorities, migrant campsites. The dialogue between the author's analysis and the images is extremely rich, even though the reader remains curious about the conditions of production of some photographs. 
Since the decline of rubber in 1910, ruins have invaded the Amazon landscape, with phantasmagorias cities, demographic decline, and a trail of misery and tropical diseases. The ideologues of the Estado Novo choose the Amazon as a national imperative, investing it with many meanings: the interior to be developed by the centralized state, the border to be delimited and protected, the promised land for Northeastern migrants, homeland, and the metonymy of the nation. Vargas visited Manaus in 1940, gave a speech, provided finance for migrants, opened services to increase the rubber trade, supply, public health conditions, and transport. However, the invention of the Amazon would not only be woven from 'above.' He counted on other actors and interests: regional elites, the military, doctors, and public health authorities, engineers, botanists, agronomists, geographers, literati, cordelistas and migrants.

Notwithstanding the spasmodic character of the connections between the Amazon and the international market, the history investigated in the book is above all a history of global connections. Technological transformations placed rubber - isolated, flexible, resistant, and impermeable - among the most strategic materials required by countries. In 1931, Harvey Firestone Jr. boasted of how rubber objects had become indispensable for human civilization, from the first cry of the newborn to the slow march to the tomb. Rubber fed the culture of the automobile in US society and the growth of aviation all over the world. Present in thousands of products (such as surgical gloves, shoes, preservatives, and tires), rubber revolutionized the daily life of civilians and the manufacture of military artifacts. Avoiding determinist interpretations, the author raises alerts to the fact that the technological innovations and applications of rubber in the industry were producers and products of the political, economic, and cultural changes resulting from the practices of social agents (p.55).

When the Japanese attacked Malaysia the supply of rubber was interrupted, and US attention was turned again to the Amazon. Profound divergences emerged between members of Franklin D. Roosevelt's administration. Some, such as the businessman and politician Jesse Jones, saw the Amazon as a green hell and ineluctably barbarous: since no action could transform it, the rubber had to be obtained in the most practical form possible. Others such as Vice-President Henry Wallace, saw the Amazon as a promised land, a keystone in inter-American integration, defending projects related to health, improvements, and social integration. In his outline of US action in the Amazon, the author argues about the multiplicity of intentions and practices of the United States in the region - the paradoxical results of the internal politics of this 
country - outlining a complex and original analysis of the relations between Brazil and the United States in those years.

The dialogue between US defenders of social projects parallel to the exploitation of rubber and the nationalist authorities in the Vargas government was fruitful and created joint initiatives for the formalization of labor and the establishment of minimum conditions of hygiene, health, and food. Brazilian authorities and US representatives made efforts to have an effective presence of the Brazilian state in the Amazon, with actions and strategies for the preparation and control of labor. All these practices were informed by political projects critical of mere uncompromising and inconsequent exploitation, containing both Brazilian dreams of national construction and the aspirations of the United States with the aim of establishing inter-American connections under its aegis.

The rubber tappers, in turn, emerge from the pages of the book as active social subjects. Garfield criticizes their recurrent representation as passive victims, easy to manipulate, mere playthings in the rubber campaigns. Oral reports transmitted between generations highlight personal history of enrichment with rubber. Signs of masculinity brighten the adventure of departing for the Amazon. The seasonal, mobile, and independent nature of the activity was much more attractive than the perspective of working on the Southeastern coffee plantations. The informality and mobility combatted by the state seduced men in search of work and enrichment. Furthermore, the decision to migrate was the fruit of drought and the lack of perspectives in their places of origin, but also based on informed calculations about relations of kinship, gender, and cultural values.

Analyzing the relations between Brazil and the United States concerning the Amazon in terms of reciprocal interests, the author moves away from interpretations of Brazil as a underdeveloped country victimized by Uncle Sam. However, he does not ignore the striking legacy of US war policies, which increased competition over access to and the use of resources, divergent representations of nature and disputes for the exercise of power.

In Search of the Amazon also found the proof of the suffering and misery of the rubber workers, and the tragedies of isolation and abandonment after the end of the war. However, he shows how the rubber tappers were capable of reinventing themselves in the following decades. They changed from unsuspecting adventurers to traditional people and possessors of wisdom, from 'rubber soldiers' to environmentalists, thereby obtaining international support for their struggles and interests in forestry conservation. The Amazon was 
invested with new meanings and challenges. Exploring regional, national, and global connections in the rubber saga in the Second World War, Garfield problematizes the nature of the region, presenting his reader with an instigating panorama of the Amazon as a socially produced place, a continuous arena of conflicts and struggles in the game of contemporary history, the scenario of guaranteed controversies in the times that would come.

\section{REFERENCES}

BLOCH, Marc. Introdução à História. 4.ed. Lisboa: Publicações Europa-América, s.d. 